UDC 614.2: 614.484

DOI: 10.21668/health.risk/2019.1.09.eng

Read

\title{
DEVELOPING METHODICAL APPROACHES TO MANAGING RISKS OF AIRBORNE INFECTIONS WITH AEROSOL CONTAGION
}

\author{
N.V. Shestopalov ${ }^{1,3}$, A. Yu. Skopin ${ }^{1,2}$, L.S. Fedorova ${ }^{1}$, T.V. Gololobova ${ }^{1,3}$ \\ ${ }^{1}$ Science Research Institute for Disinfectology of the Federal Service for Surveillance over Consumer Rights \\ Protection and Human Well-being, 18 Nauchniy lane, Moscow, 117246, Russian Federation \\ ${ }^{2}$ I.M. Sechenov's First Moscow State Medical University, bld. 2, 8 Trubetskaya Str., Moscow, 119991, \\ Russian Federation \\ Russian Medical Academy for Continuing Professional Education of the RF Public Healthcare Ministry, bld. 1, \\ 2/1 Barrikadnaya Str., Moscow, 125993, Russian Federation
}

A promising way to prevent spread of airborne infections with aerosol contagion and to reduce risks of healthcareassociated infections (HAI) is to preserve clean air inside premises (including medical organizations) via performing activities aimed at disinfecting air, ventilation and air-conditioning systems and via switching to up-to-date ecologically friendly disinfectants and their rotation.

Epidemiological hazards for patients and medical personnel in medical organizations are caused by pathogenic and opportunistic pathogenic microorganisms that can be found in the air inside premises and on various surfaces; such microorganisms are bacteria in their vegetative form (including tuberculosis agents), viruses, fungi that cause candidosis and dermatophytes, mold fungi, spore bacteria.

Aerosol disinfection is a well proven technique for treating the air inside premises in order to disinfect it and to reduce risks of infections spread; this technique involves transforming a disinfectant into a fine-disperse state with a specialized spraying device so that an aerosol is introduced into the air inside a premise.

To work out efficient air disinfection regimes that involve application of relevant equipment and disinfectants, it is necessary to apply such techniques and conditions that would secure the most efficient application of aerosol disinfection in practical conditions.

The authors have outlined basic organizational and methodical approaches to an objective assessment of how efficient and how safe aerosol disinfection technique is when it is applied in different premises, including medical organizations.

Key words: air decontamination, air disinfection, aerosol disinfection technique, Assessment of disinfectants efficiency, disinfectant aerosol, examination of decontamination efficiency, airborne infections with aerosol contagion, aerosol chamber.

At present morbidity with respiratory infections still remains high in Russia. In spite of more and more activities aimed at preventing infections, there are considerable risks of prevalence and growing morbidity related to airborne infections with aerosol contagion including healthcare-associated ones (HAI) [1-7]. In 2017, just like in previous years, acute respiratory infections (ARI) took the first place among infec-

tious and parasitic diseases in the Russian Federation; they predominantly occurred in the upper respiratory tracts in multiple or unspecified locations. Over the last 6 years (2012-2013) morbidity with ARI has grown by $9.3 \%$ in the Russian Federation. In 2014 there was a slight decrease in it down to $19,506.00$ per 100 thousand people but then a gradual increase followed up to its previous values and even above [8].

(C) Shestopalov N.V., Skopin A. Yu., Fedorova L.S., Gololobova T.V., 2019

Nikolay V. Shestopalov - M.D., Professor, Head, Professor at the Department for Organization of the State Sanitary and Epidemiological Service (e-mail: shestopalov.nv@gmail.com; tel.: +7 (495) 332-01-01; ORCID: https://orcid.org/0000-0002-9973-3508).

Anton Y. Skopin - Ph.D. of Medical Sciences, Associate Professor, Head of the Laboratory dealing with sterilization issues, Associate Professor at the Department for General Hygiene (e-mail: auskopin@yandex.ru; tel.: +7 (495) 332-01-65; ORCID: https://orcid.org/0000-0001-7711-9489).

Lyudmila S. Fedorova - M.D., Professor, Head of the laboratory dealing with disinfection issues (e-mail: fedorova-ls@ yandex.ru; tel.: +7 (495) 332-01-60; ORCID: https://orcid.org/0000-0001-2663-0273).

Tatiana V. Gololobova - M.D., Deputy Head of the Science Research Institute for Disinfectology, Professor at the Department of tropical, parasitic diseases and disinfection care (e-mail: 1915544@mail.ru; tel.: +7 (495) 332-01-15; ORCID: https://orcid.org/0000-0001-9033-5223). 
In $201721.66 \%$ of the overall country population had ARI, 79\% of them being children younger than 17. More than 31.77 million ARI cases were registered in Russia, and morbidity amounted to $21,664.01$ per 100 thousand people. Children under 17 prevail among patients with ARI, with their share accounting for $73.16 \%$ in 2017 [8].

Air as a natural aerosol is a perfect medium that makes for contagion of respiratory infections [9]. Vast quantity of microorganisms in any room occur in a dust environment and tend to accumulate in it, concentrate in places that are hard-to-get; these microorganisms move together with air flows thus creating potential infection foci [10-12].

Dust particles can bear up to $95 \%$ of all microorganisms that occur in the indoor air. Since some infectious agents are rather resistant, various places in the environment, especially indoors, that are hard-to-get become massively infected due to dust accumulating in them [13].

Moreover, surfaces that can be found indoors usually have a lot of defects, such as pockets, cracks, capillaries and so called crypts (small craters). Any surface even if it seems ideally smooth has a lot of crypts which can be seen only under a high magnification; microorganisms are able to survive any chemical attack in these tiny craters and then reproduce themselves, return onto a surface and make a population grow.

All the above mentioned causes and elevates risks that infectious agents penetrate a body and makes it especially pressing to create and improve objective techniques for assessing efficiency of disinfectants, equipment, and technologies applied for air disinfection.

It is vital to find such a treatment technology that can guarantee disinfection in all hard-to-get places as it will eventually allow to prevent negative outcomes that microbe contamination in the indoor air may have, to reduce risks of biological emergencies including those that can possibly occur in overcrowded places $[14,15]$.

Aerosol disinfection is one of such technologies; it involves transferring a liquid disinfectant into a fine-disperse state and its introduction into the air inside a room. An aerosol fills the overall space and deposits on surfaces of objects (walls, floor, equipment and devices). Aerosol drops partially evaporate and thus penetrate all the cracks, holes, and notches; it makes for greater and more efficient interaction between a disinfectant and a microbe cell resulting in its death [16].

An ordinary drop which is not created with technological equipment can't penetrate tiny surface defects due to osmotic laws; it can only jam them for some time. Aerosol particles with ultra-small sizes $(5-35 \mu \mathrm{m})$ can penetrate anywhere and it, due to adhesion and heat precipitation, allows them to fill all tiny surface defects thus covering this surface evenly and completely; they can also treat an air space where microorganisms migrate due to convection flows $[12,17]$.

Aerosol disinfection is well known to be successfully applied for disinfecting air and surfaces in medical and public organizations all over the world. Overall requirements to choice on equipment, chemical disinfectants and treatment technologies for air disinfection in medical organizations via aerosol spraying are fixed in the Methodical guidelines on aerosol disinfection in medical organizations ${ }^{1}$. However, the Guidelines don't fix any requirements to conditions and a procedure for an examination of equipment and substances which are to be applied for aerosol disinfection; and surely, such examinations are necessary for working out efficient disinfection modes.

It is vital to obtain objective assessment whether aerosol disinfection is efficient and

\footnotetext{
${ }^{1}$ Methodical guidelines on aerosol disinfection in medical organizations: Methodical guidelines MR 3.5.1.0103-15. M.: The Federal Service for Surveillance over Consumer Rights Protection and Human Well-being, 2015. - 11 p.
} 
safe when applied inside various buildings and rooms, including medical organizations; to do that, the Test Laboratory Center at the Rospotrebnadzor's Scientific Research Institute of Disinfectology organizes and performs laboratory-experimental examinations aimed at determining efficiency and safety of disinfectants and specific equipment for spraying them (aerosols generators) as well as any other equipment used for disinfecting air and surfaces inside.

It should be noted that any study on efficiency of air disinfections under laboratory conditions is rather labor-consuming, both in terms of its organization and methodical support, and it requires strict adherence to requirements fixed in various regulatory and legal documents and applied to laboratory rooms, equipment, and working procedures for handling microorganisms aerosols and chemicals. The existing experience related to aerosol disinfectants examinations indicates that efficiency of such substances to a certain extent depends on several factors, such as chemical structure of a substance (an active ingredient and its concentration in a working solution of a substance), what quantity of a substance is spent per a unit volume and area in a room, aerosol dispersity, duration of a disinfection cycle and a number of cycles required, conditions for applying a substance (preventive disinfection, or focal disinfection applied to prevent different infections taking into account an infectious agent), persistence of an aerosol in the air.

Our research goal was to substantiate and implement complex methodical approaches to organizing and conducting examinations on safety and efficiency of disinfectants aimed at solving tasks related to managing health risks.

Data and methods. We applied microorganisms which were significant from a sanitary point of view (Staphylococcusaureus, strain 906, ATCC 6538-P) as our test ones; they were applied to artificially contaminate air so that it became possible to examine efficiency of disinfectants which were sprayed as an aerosol as well as efficiency of disinfecting equipment. We took Mycobacteriumterrae, DSM 43227, to assess tuberculocidal effects produced by disinfectants. These microorganisms belong to III-IV pathogenicity category as per a classification used in the RF (SER 1.3.2322-08 "Safe handling of microorganisms belonging to III-IV pathogenicity (hazard) category and parasitic pathogens" ${ }^{2}$, which is equivalent to the first pathogenicity category as per World Health Organization classification. It to a larger extent determines specificity and scope of requirements to rooms, equipment, and working procedures for handling such microorganisms.

The research was accomplished in conformity with sanitary-epidemiologic rules SER 1.3.2322-08 "Safe handling of microorganisms belonging to III-IV pathogenicity (hazard) category and parasitic pathogens". There is a great variety of existing disinfecting devices used for creating aerosols with different technical and operating features as well as parameters that determine efficiency of air disinfection modes. Therefore, to examine efficiency and safety of such equipment, we need to create conditions that are as close to its practical application as is only possible. Besides, functional peculiarities of various aerosol generators, namely their capability to treat rooms with different volumes, made it necessary to construct several chambers with different volumes to test various pieces of equipment depending on their power and functions.

The task was to examine efficiency of disinfectants (including aerosol tanks) aimed at disinfecting surfaces in a closed room with a limited volume (for example, inside a car

\footnotetext{
${ }^{2}$ Safe handling of microorganisms belonging to III-IV pathogenicity (hazard) category and parasitic pathogens: Sanitary rules SR 1.3.2322-08. - M.: Rospotrebnadzor's Federal center for Hygiene and Epidemiology, 2009. - 75 p.
} 
cabin). To solve it, we applied an aerosol chamber with its volume equal to $1 \mathrm{~m}^{3}$, which was actually a confined box belonging to the III biological safety category; such a box provides protection for a researcher, a product and an environment. The chamber was equipped with an exhaust ventilation driven mechanically via a rigid air duct. It had HEPAfilters belonging to $\mathrm{H} 14$ category for fine air purification as well as necessary operating holes for air inflow under pressure in order to create microorganisms aerosol and subsequent air sampling to assess how efficient air disinfection was (Figure 1).

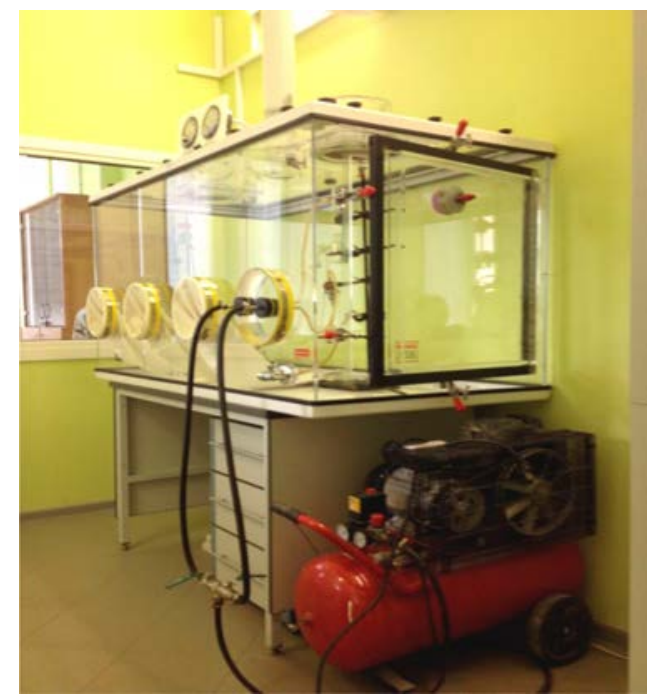

Figure 1. The aerosol chamber for examining efficiency of disinfecting aerosols

Our goal was to examine efficiency of disinfecting equipment applied to disinfect air in rooms with great volumes; to do that, we used room-chambers with their volumes up to $120 \mathrm{~m}^{3}$, specifically equipped with technical devices necessary for handling microorganisms belonging to III-IV pathogenicity category. A room-chamber used for the above-mentioned purposes with its volume being $120 \mathrm{~m}^{3}$ is a box which can be hermetically sealed and which is equipped with a mechanic supply-and-exhaust ventilation system with HEPA-filters belonging to $\mathrm{H} 14$ category for fine air purification installed both at an air supply point and an air exhaust one. The chamber inside is finished with specific covering materials which can withstand systematic treatment with disinfecting aerosols containing aggressive active ingredients. Open bactericidal irradiators are installed along the perimeter of the chamber which are applied to disinfect working volume air after experimental work with microorganisms is over. Safety for a researcher was provided with an obligatory kit for individual skin protection (protective overalls, rubber gloves, a cap) and respiratory organs protection (respirators or masks), first aid means, as well as alarm system buttons inside the box and in the forebox with the light and sound alarm system being brought out into the corridor (Figure 2).

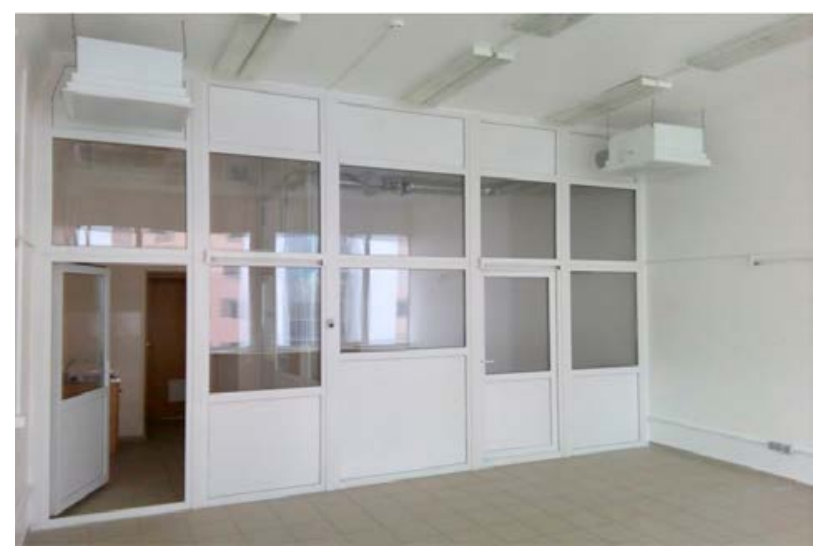

Figure 2. The chamber for examining efficiency of disinfecting aerosols

Another task was to determine bactericidal doses of impulse ultraviolet irradiation in a continuous spectrum that could provide 90-99.99\% efficiency when disinfecting air and surfaces contaminated with $S$. aureus bacteria [18]; to solve it, we applied specialized rooms in order to assess efficiency of disinfectants and disinfection equipment.

Research on efficiency of air disinfection with an aerosol generator involved creating a microbe suspension that was evenly distributed over the overall volume of a room with a ventilator. Preliminary series of experiments confirmed that contamination with an air suspension was stable during the whole experiment. Initial air contamination amounted to $1.46-4.80 \times 10^{5} \mathrm{CFU} / \mathrm{m}^{3}$. Air 
samples were taken with an aspirator that was pumping air through Drexel bottles filled with sterile tap water; the water was then evenly applied on Petri dishes and poured over with $10 \mathrm{ml}$ of meat-peptone agar which had been previously melted and then cooled down to $45{ }^{\circ} \mathrm{C}$. The results were estimated after 24-48-hour incubation under $37 \pm 1^{\circ} \mathrm{C}$. The same measurements obtained from air which had not been irradiated with impulse ultraviolet flows were used as control samples.

An impulse ultraviolet irradiation generator was put in the center of a chamber with its overall volume being equal to about $30 \mathrm{~m}^{3}$ (length equal to $3.1 \mathrm{~m}$; width, $2.4 \mathrm{~m}$; height, $4.0 \mathrm{~m}$ ) and switched on an irradiation mode from $1 \mathrm{~min} 31 \mathrm{sec}$ to $5 \mathrm{~min} 6 \mathrm{sec}$ [18].

When examining how efficient disinfection was in case of surfaces, we applied test microorganisms on the following materials: plastic (disposable Petri dishes with their diameter being equal to $85 \mathrm{~mm}$ ), metal (metal plates sized $50 \times 50 \mathrm{~mm}$, made of stainless steel), and tile (tile plates sized $50 \times 50 \mathrm{~mm}$ ).

We additionally applied $40 \%$ inactivated serum on a preliminary contaminated plastic surface to imitate its further organic contamination; it was done to examine influence exerted on efficiency of disinfection in case of organic contamination on irradiated surfaces.

All examined test-objects were irradiated with impulse ultraviolet irradiation from 2-meter distance. The generator was placed in such a way that allowed to exclude any influence exerted by a reflecting surface on bactericidal flow value on an irradiated surface (Figure 3).

Test surfaces were contaminated with a suspension, its initial contamination being equal up to $2.0 \times 10^{7} \mathrm{CFU} / \mathrm{cm}^{2} .0 .25 \mathrm{ml}$ of the suspension were put on samples surfaces with a micro-pipette and then evenly spread with a spatula and dried in a thermostat. Average microorganisms quantity on control plastic samples (which hadn't been irradiated) amounted to $1.0 \times 10^{6} \mathrm{CFU} / \mathrm{cm}^{2}$; metal

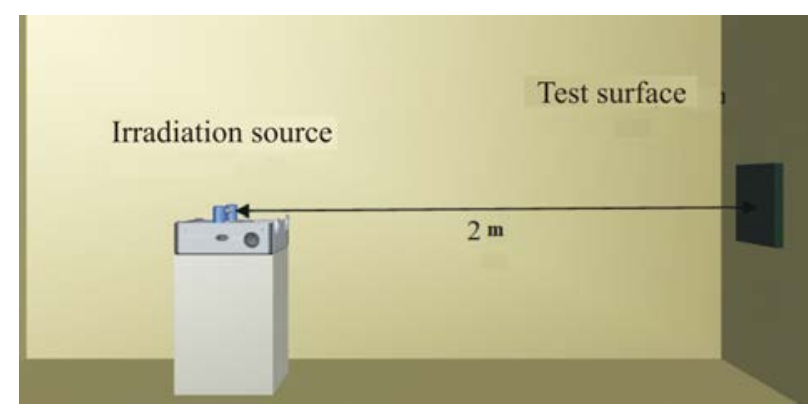

Figure 3. A scheme showing disinfection of test surfaces contaminated with S. aureus, with an impulse ultraviolet irradiation generator [18]

samples, $3.7 \times 10^{5} \mathrm{CFU} / \mathrm{cm}^{2}$; tile samples, $2.77 \times 10^{4} \mathrm{CFU} / \mathrm{cm}^{2}$. The obtained test-samples were exposed to ultraviolet irradiation for a period from 1 to 32 minutes. After the test was over, $10 \mathrm{ml}$ of sterile water were put into irradiated and control plastic samples (disposable Petri dishes), microbe cells were washed off surfaces with a spatula and evenly distributed in washout liquid. Then $10 \mathrm{ml}$ of meat-peptone agar which had been previously melted and then cooled down to $45^{\circ} \mathrm{C}$ were poured into Petri dishes. We examined two groups of control surfaces. Microorganisms were washed off the surfaces in the first group before the experiment started (before the suspension was dried a little); in the second group, after the experiment (3 hours after). Overall microorganisms quantity in washouts from the control surfaces was taken as an average before and after the experiment. All the experiments were repeated three times.

Results and discussion. Table 1 contains the results of our research on efficiency of disinfecting air contaminated with $S$. aureus in a specialized chamber with an impulse ultraviolet irradiation generator.

Volume bactericidal doses that can disinfect air with $90 \%$ efficiency are equal to $14 \mathrm{~J} / \mathrm{m}^{3}$, and with $99.9 \%, 47.5 \mathrm{~J} / \mathrm{m}^{3}$. $100 \%$ disinfection efficiency is reached after an exposure that lasts for 5 minutes 6 seconds.

We examined efficiency of disinfecting plastic test-objects with impulse ultraviolet irradiation in a continuous spectrum with disposable Petri dishes in tow series of experiments (Figure 4). 
Table 1

Efficiency of disinfecting air contaminated with S.aureus with an impulse ultraviolet irradiation generator [18]

\begin{tabular}{|c|c|c|c|c|c|}
\hline $\begin{array}{c}\text { Volume } \\
\text { of an } \\
\text { experi- } \\
\text { mental } \\
\text { box, } \mathrm{m}^{3}\end{array}$ & $\begin{array}{c}\text { Irradia- } \\
\text { tion } \\
\text { period }\end{array}$ & $\begin{array}{c}\text { Control, } \\
\text { CFU } / \mathrm{m}^{3}\end{array}$ & $\begin{array}{c}\text { Test, } \\
\text { CFU } / \mathrm{m}^{3}\end{array}$ & $\%$ & $\mathrm{l}$ \\
\cline { 4 - 7 } & $\begin{array}{c}5 \mathrm{~min} \\
6 \mathrm{sec}\end{array}$ & $4.8 \times 10^{5}$ & 0 & 100.00 & 5.6 \\
\cline { 2 - 7 } 30 & $\begin{array}{c}3 \mathrm{~min} \\
3 \mathrm{sec}\end{array}$ & $1.46 \times 10^{5}$ & 80 & 99.95 & 3.2 \\
\cline { 2 - 7 } & $\begin{array}{c}1 \mathrm{~min} \\
31 \mathrm{sec}\end{array}$ & $1.63 \times 10^{5}$ & $2.4 \times 10^{3}$ & 98.50 & 1.8 \\
\hline
\end{tabular}

Figure 4 represents a survival curve built up after two series of experiments taking into account all the previous research [18]. The survival curve is a typical 2-component one. $99.99 \%$ disinfection efficiency is reached even after 1-minute exposure to irradiation from a 2-meter distance.

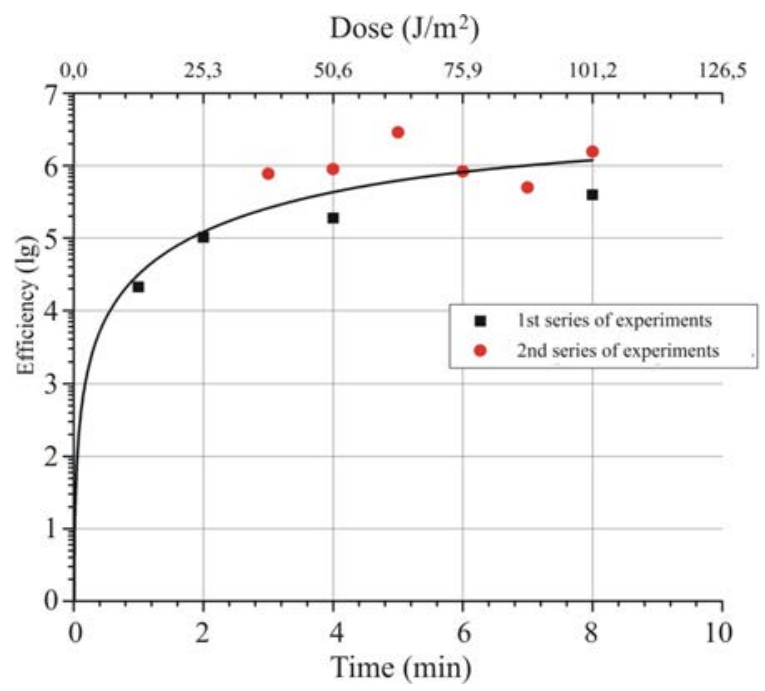

Figure 4. Efficiency of disinfections applied on plastic test-objects under various exposure to impulse ultraviolet irradiation

Figure 5 shows the results of research on influence exerted by a surface material and occurrence of organic contaminants on disinfection efficiency [18]. The research revealed that when test-objects were exposed to 2-minute irradiation, disinfection efficiency was not less than $99.99 \%$ on all examined surfaces or, in other words, it corresponded to an efficiency criterion fixed for the process. Disinfection was the most efficient on plastic and tile test-objects, and the lest efficient on metal ones. Biological contamination (biological burden) on a plastic surface doesn't have any substantial influence on attainable efficiency. The discrepancy between disinfection efficiency for plastic surfaces with biological burden and without it doesn't exceed 10 minutes under any exposure (from 2 to 8 minutes).

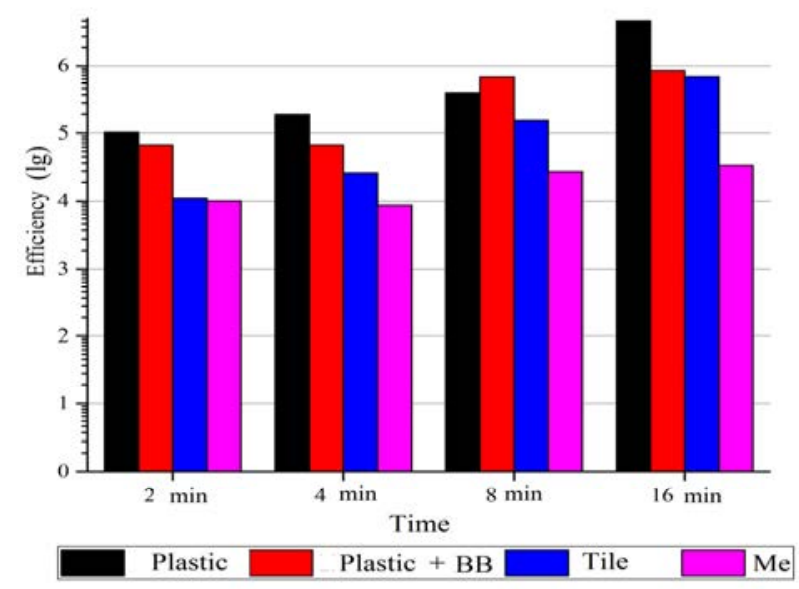

Figure 5. Influence exerted by a surface material and organic burden on efficiency of disinfection with impulse ultraviolet irradiation

As regards examining efficiency of chemical aerosol disinfectants, the greatest efficiency in terms of surfaces treatment was revealed for substances based on hydrogen peroxide with various additives, chlorine dioxide, and cation surface-active substances, and it is well in line with previously obtained data [19]. Substances were discharged in quantities within $10-50 \mathrm{ml} / \mathrm{m}^{3}$, disinfection exposure lasted from 60 to 240 minutes, aerosol dispersity varied from 5 to $30 \mu \mathrm{m}$ ("dried" and "moistened" spray). We should note that if a substance is discharged in greater quantities or exposure lasts longer, the efficiency also grows; but if aerosol dispersity and active ingredient concentration in a working solution go up, it doesn't necessarily lead to a positive outcome. An aerosol reached its maximum efficiency when particles size was 10-20 $\mu \mathrm{m}$ ("moistened" spray) for most examined substances. 
Softer modes are more efficient for air disinfection (both in terms of substance discharge and exposure duration), but surfaces disinfection requires harder ones; it is due to different physical and chemical interaction between disinfectant aerosols and microorganisms in the air and on surfaces.

Taking into account multi-factor impacts exerted by parameters determining disinfection efficiency in a laboratory on an actual disinfection taking place in practical conditions, and bearing in mind, that efficiency of such activities is the most important epidemiologically in rooms inside medical organizations ${ }^{3}$ that belong to A class of purity (the purest ones), we should make an environment inside a chamber for examining how efficient aerosol disinfection is as close to that existing in real life as its only possible.

When we model an environment inside a chamber and equip it with relevant pieces of furniture or medical devices, it allows to calculate standards for disinfectant discharge properly, taking into account not only a volume of a room but also total surfaces square which becomes greater due to objects placed inside it. The latter should be calculated when creating efficient modes for surfaces disinfection with aerosols. Besides, if we use real model objects made of the same materials as medical furniture and devices, it allows us to achieve high precision in creating efficient modes for surfaces disinfection in rooms inside medical organizations that belong to A class of purity (the purest ones). When doing it, we should try to obtain minimal efficient concentrations of active ingredients in order to provide maximum possible safety of disinfection procedures for medical personnel and patients as well as to reduce aggressive impacts exerted by disinfectants on treated surfaces and to preserve their operational properties.

Conclusion. When examining and assessing efficiency of equipment and disinfectants applied for aerosol disinfections, one should envisage both proper methodical support for research and competent experts as well as relevant technical support in a laboratory provided with specialized validated test equipment which can be applied for a complex disinfectiological examination.

So, we have developed and tested methodical approaches to assessing efficiency of disinfectants and equipment applied for aerosol disinfection; these approaches allow to work out efficient modes for air treatment and eventually to make disinfectant activities more efficient in practical conditions thus reducing risks of airborne infections with aerosol contagion, including HAI.

Funding. The research was not granted any sponsor support.

Conflict of interests. The authors state there is no any conflict of interests.

\section{References}

1. Badamshina G.G., Ziatdinov V.B., Isaeva G.Sh., Kirillova M.A., Zemskova S.S. Analiz riska razvitiya infektsii, svyazannykh s okazaniem meditsinskoi pomoshchi [Analysis of risk for infections related to providing medical assistance]. Analiz riska zdorov'yu, 2017, no. 2, pp. 113-118 (in Russian).

2. Galai V.S. Analiz biozagryaznenii vozdushnoi sredy v chistykh pomeshcheniyakh i otsenka riskov zarazheniya $\mathrm{v}$ nikh [Analysis of biocontaminations of air environment in clean rooms and estimation of risks of their contamination]. Vestnik Moskovskogo gosudarstvennogo stroitel'nogo universiteta, 2017, vol. 12, no. 8 (107), pp. 912-916 (in Russian).

\footnotetext{
${ }^{3}$ SER 2.1.3.2630-10 "Sanitary-epidemiologic requirements to organizations operating in public healthcare or performing medical activities" [web-source]. - URL: http://docs.cntd.ru/document/902217205 (date of visit November 3, 2018).
} 
3. Ziatdinov V.B., Badamshina G.G., Bakirov A.B., Zaripova A.Z., Isaeva G.Sh., Karimov D.O. Mikrobiologicheskii monitoring vozdushnoi sredy v meditsinskikh organizatsiyakh [Microbiological monitoring of the air environment in medical institutions]. Meditsina truda i ekologiya cheloveka, 2016, vol. 8, no. 4, pp. 86-90 (in Russian).

4. Punchenko O.E., Kosyakova K.G., Vasil'eva N.V. Issledovanie mikrobioty vozdukha v mnogoprofil'nom statsionare Sankt-Peterburga [Investigation of the air microbiota in the multidisciplinary hospital of Saint Petersburg]. Gigiena i sanitariya, 2014, no. 5, vol. 93, pp. 33-36 (in Russian).

5. Curtis L.T. Prevention of hospital-acquired infections: review of non-pharmacological interventions. Journal of Hospital Infection, 2008, vol. 69, no. 3, pp. 204-219.

6. Eames I., Tang J.W., Li Y., Wilson P. Airborne transmission of disease in hospitals. Journal of the Royal Society. Interface, 2009, vol. 6, no. 6, pp. 697-702.

7. Jacob. J.T., Steinberg J.P., Kasali A., Zimring C., Denham M.E. The role of the hospital environment in preventing healthcare-associated infections caused by pathogens transmitted through the air. Health Environments Research \& Design Journal, 2013, vol. 7, no. 1, pp. 74-98.

8. O sostoyanii sanitarno-epidemiologicheskogo blagopoluchiya naseleniya v Rossiiskoi Federatsii v 2017 godu: Gosudarstvennyi doklad. - Moscow, Federal'naya sluzhba po nadzoru v sfere zashchity prav potrebitelya i blagopoluchiya cheloveka, 2018, 108 p. (in Russian).

9. Morris C.E., Leyronas C., Nicot P.C. Movement of bioaerosols in the atmosphere and the consequences for climate and microbial evolution. Aerosol Science: Technology and Applications, 2014, pp. 393-415.

10. Li Y., Qian H., Leung G.M., Tang J.W., Yang X. [et al.]. Role of ventilation in airborne transmission of infectious agents in the built environment - a multidisciplinary systematic review. Indoor Air, 2007, vol. 17, no. 1, pp. 2-18.

11. Wu. Y., Chen A., Luhung I., Gall E.T., Chang V.W.-C. [et al.]. Bioaerosol deposition on an air-conditioning cooling coil. Atmospheric Environment, 2016, vol. 144, pp. 257-265.

12. Le Cann P., Bonvallot N., Glorennec P., Deguen S., Goeury C. [et al.]. Indoor environment and children's health: recent developments in chemical, biological, physical and social aspects. International Journal of Hygiene and Environmental Health, 2011, vol. 215, no. 1, pp. 1-18.

13. Isaeva G.Sh., Ziatdinov V.B., Gabidullina S.N. Gigienicheskii i mikrobiologicheskii monitoring vozdushnoi sredy $\mathrm{v}$ nachal'noi shkole [The hygienic microbiological monitoring of air in grade school]. Zdravookhranenie Rossiiskoi Federatsii, 2016, vol. 60, no. 2, pp. 83-88 (in Russian).

14. Nagolkin A.V., Volodina E.V., Akimkin V.G., Borisoglebskaya A.P., Safatov A.S. Obezzarazhivanie vozdukha $\mathrm{v}$ meditsinskikh organizatsiyakh: tendentsii razvitiya [Air disinfection in medical institutions: development trends]. Meditsinskii alfavit, 2015, vol. 1, no. 6, pp. 44-49 (in Russian).

15. Savenko S.M., Logvinov N.L. Kak effektivno prervat' vozdushno-kapel'nyi put' rasprostraneniya vnutribol'nichnykh infektsii - odnu iz naibolee rastushchikh problem sovremennogo zdravookhraneniya? Meditsinskii alfavit, 2017, vol. 3, no. 30 (327), pp. 21-22 (in Russian).

16. Yuzbashev V.G., Abramova I.M. Tekhnologii obezzarazhivaniya I ochistki vozdukha vazhnoe zveno v profilaktike tuberkuleza (analiticheskii obzor). Meditsinskii alfavit, 2012, vol. 1, no. 3, pp.12-18 (in Russian).

17. Nagolkin A.V., Volodina E.V., Akimkin V.G., Borisoglebskaya A.P., Safatov A.S. Inaktivatsiya mikroorganizamov - glavnyi kriterii effektivnosti obezzarazhivaniya vozdukha $\mathrm{v}$ meditsinskikh organizatsiyakh [Microbial inactivation is a major criterion for the efficiency of air disinfection in health care facilities]. Epidemiologiya i infektsionnye bolezni. Aktual'nye voprosy, 2014, no. 6, pp. 57-62 (in Russian).

18. Shestopalov N.V., Akimkin V.G., Fedorova L.S., Skopin A.Yu., Gol'dshtein Ya.A., Golubtsov A.A., Kireev S.G., Polikarpov N.A., Shashkovskii S.G. Issledovanie bakteritsidnoi effektivnosti obezzarazhivaniya vozdukha i otkrytykh poverkhnostei impul'snym ul'trafioletovym izlucheniem sploshnogo spektra [Research of germicidal efficiency of air and open surfaces disinfection 
by pulsed ultraviolet light of continuous spectrum]. Meditsinskii alfavit, 2017, vol. 2, no. 18, pp. 5-9 (in Russian).

19. Popov D.A., Anuchina N.M. Microbiological efficacy of hospital environment decontamination by hydrogen peroxide aerosol. Biomedical Engineering, 2016, vol. 50, no. 2, pp. 92-95.

Shestopalov N.V., Skopin A.Yu., Fedorova L.S., Gololobova T.V. Developing methodical approaches to managing risks of airborne infections with aerosol contagion. Health Risk Analysis, 2019, no. 1, pp. 84-92. DOI: 10.21668/health.risk/2019.1.09.eng

Received: 08.11.2018

Accepted: 24.02 .2019

Published: 30.03.2019 